\title{
THE DEVELOPMENT STRATEGY OF THE SUGAR INDUSTRY IN THE CONTEXT OF EUROPEAN INTEGRATION OF UKRAINE
}

\author{
Yuliya ONYSHCHUK', \\ Vinnitsia National Agrarian University, Ukraine
}

\begin{abstract}
The main problem of the Ukrainian economy today is the total loss of production potential. Losing production, the country becomes an outsider in the world economy, "falls out" of the system of international division of labour, giving leadership in the production of traditional goods for it to countries with lower benefits, but more civilized approach to production. One of these traditional products, which have always been "calling card" of Ukraine is sugar. Methodology. The basis for the study of the sugar industry, we have chosen a systematic approach, in which the industry is seen as complex, complete system structural elements, united by a common purpose. At the same time, then the sugar industry is food processing subsystem, part of the process and part of agriculture. Research industry as system and component of a higher order corresponds to the need to maximize the efficiency of its development. The development of the sugar industry in Ukraine should not be a simple transition from one system to another as and complex multifactorial process that represents the law of transition of quantitative changes in quality. Implementation of the main goal of the sugar industry in a dynamic environment is possible only if the selection and implementation of effective strategies must be built into the strategy of agricultural development and national economic strategy. Therefore, the subject of our research are theoretical and applied aspects of effective development of the sugar industry of Ukraine and the purpose of research - strategy development sector in terms of European integration. Results. Under the development strategy of the sugar industry, we understand the unique set of actions and decisions on how to achieve development with minimal energy system. We believe that the strategic goal should be a creation of modern, technically perfect, economically efficient and socially important sugar industry, able to produce competitive products, satisfy the full domestic demand for sugar, to ensure the formation of the state reserve and expand the export base. To achieve this, the industry has a number of assumptions that are regarded as its capabilities, as well as a number of restrictions that impede the development process can significantly influence the content of the strategy or the process of implementation and require removal. Together they form the strategic position of the sugar industry, which today we can characterize as extremely weak. Achieving strategic objective involves the development and implementation of a package of measures which we have divided into three areas: restructuring measures, technical and technological modernization of the industry diversification of production activities and measures of organizational and economic modified sugar production. Value/originality. The implementation of the proposed measures will overcome the crisis on the first phase, on the second - stabilize production and create conditions for increasing it in the future and, finally, ensure economic growth in the long term.
\end{abstract}

Key words: sugar industry, sector, strategy, development, modernization, restructuring.

JEL Classification: L66, M20, 01

\section{Introduction}

The nowadays critical situation of the sugar industry in Ukraine requires urgent action to tackle the crisis, stabilize the industry and economic growth in the long term. The only effective tool to solve this problem is to develop an effective, science-based strategy for recovery and further development of sugar industry. The strategy is a practical activity, a set of unique actions that achieve goals based on the rational use of resources and subjected to constant impact of changes in the environment. The unique strategy is a strategic vision for the development of the sugar industry in Ukraine considering the situation in the world and available potential that still remains. Without a sound, effective strategy for industry development trajectory remains unclear, and its prospects - unpredictable.

The complexity of the current situation depends not only on the deep decline of sugar in Ukraine, but also a high degree of instability of national and world economy,

Corresponding author:

${ }^{1}$ Department of Administrative Management and Alternative Energy Recourses, Vinnitsia National Agrarian University.

E-mail: onyshchukyulia@mail.ru 
which makes high demands on the quality of strategy for its flexibility and adaptability, requires more attention to details. In other words, uniqueness is the main feature of the development of strategy of the sugar industry in Ukraine. It must neutralize threats, and use the potential, and enhance weaknesses of the industry. It's very relevant under conditions of deepening European integration, when the requirements for effective activity, competitiveness, technical and technological level of sugar Ukrainian grow repeatedly.

In view of the main features of the sugar industry, which not only consists of several subsystems and components, and itself is a subsystem of agriculture, its development strategy must be consistent and fit into the overall strategy of agricultural development of the country.

Therefore, the subject of our research are theoretical and applied aspects of effective development of the sugar industry of Ukraine and the purpose of research - strategy development sector in terms of European integration.

\section{The aims and objectives of the strategy}

The process of developing a strategy is a sequence of stages, the main ones are: defining the mission field, formulating strategic goals and specification of a subgoals, objective analysis of the possibilities and limitations justify actions and choices of alternatives that achieve the strategic goal, development strategy implementation mechanism.

The mission of the sugar sector in Ukraine is determined by its traditional role in the social and production needs of the population and food industry in one of the most important consumer basket of food - sugar.

Talking about strategy of the development of the industry, while forming strategic goal should focus on a desired result of this process, the achievement of which ultimately clearly characterize the efficacy of the strategy. Thus, the strategic goal of development is to create a modern, technically perfect, economically efficient and socially important sugar industry, able to produce competitive products, satisfy the full domestic demand for sugar, to ensure the formation of the state reserve and expand the export base.

Achieving the strategic goals ensured the consistent implementation of the objectives of lower level, including: - Overcoming the crisis in the sector;

- Stabilization of production and creating conditions for its extension in the future;

- Ensuring sustainable economic growth.

Decomposition of strategic objectives allows to specify the tasks facing the sugar industry, and outline time horizons, defining priorities and future ones.

As optimality criteria by which the estimated impact of the objectives in the first case should be selected to minimize losses in the second - break-even condition, and the third - the maximization of profit for the current state of the sugar market and existing facilities industry.

\section{The possibilities and limitations}

The probability of achieving the strategic goal primarily depends on available opportunities and constraints that influence the effectiveness and efficiency of development strategy. Available in development potential can be used as the starting point of exit from the crisis and ensure future growth, it includes:

- Stable demand in the domestic market;

- Inexhaustible potential for increasing the resource base;

- The possibility of a comprehensive recycling and waste management, development of modern modes of production, including energy;

- Existing technical potential of the sector;

- Formed human resources;

- Infrastructure software industry;

- The existing institutional framework.

Throughout the history of the functioning of the sugar industry in Ukraine demand for sugar showed more or less stable trend and, despite reducing its volume during the last decade primarily due to depopulation principle fall has not occurred. Given the stability of domestic demand can consider it as a primary factor in the rationale for the development of the sugar industry in Ukraine. In support of this possibility evidenced by the intense competition on the international market by cane sugar, as well as the manufacturers of more expensive products that are subsidized by their countries, high transport costs of imported sugar - all these factors make Ukrainian sugar producers a competitive advantage in the domestic market in the foreseeable future. In addition, as noted in Chapter Two, Ukraine has unique conditions for self-sufficiency of sugar beet, which can be considered an absolute competitive advantage not only in domestic but also in the international market of sugar. Creating appropriate incentives for the development of Sugar beet can provide almost unlimited resources.

The sugar industry provides a range of sectors, not only sugar, but its production waste, which is a valuable raw material, such as for alcohol industry, animal husbandry, agriculture, energy, mining and others. The most promising direction using waste sugar production today recognized an industrial production of high-octane additives, bioethanol, biogas and organic fertilizer. Using these capabilities not only save the sugar industry in our country, and give it a new impetus to development. In particular, Brazil, the world leader in the production of sugar, recycles only about half grown sugar cane, and the rest used to produce bioethanol. Thus the ratio of sugar cane used to solve food problems and energy problems are variable parameter that depends on energy prices and sugar. Most of Brazil's sugar mills have the capacity to produce both sugar and ethanol, but because it is the only exporter which can diversify within a year $5-10 \%$ of the capacity for processing sugar or ethanol for processing in response to changes in the profitability of these two products. This makes it flexible enough and, 
depending on the dynamics of markets sugar and ethanol can determine the scale of production and exports of both goods. This opportunity can be used in Ukraine.

Features of the sugar industry defined as technical potential, formed over the years, and although today depreciation most factories reaches 55-60\%, and fuel, raw materials, auxiliary materials per unit of production higher than those in developed European countries accumulated potential can not be ignored - it is the base from which stabilize the sugar industry and its future development. In addition, the industry is also positive examples. This is particularly powerful in Cherkasy region and one of the largest in Ukraine Palmirskiy sugar factory, which is produced daily to 18 thousand. Tons of sugar, which meet the highest quality standards and are supplied to companies focused on the use of modern food technology.

Human resources of industry are represented by technology experts, economists, managers and others. $\mathrm{He}$ also formed years of experience sugar industry, preparation of raw materials, the production process and so on. Of course, reducing the attractiveness of the industry, incentives to improve the quality of work and the deepening of disparities in pay led to the "washout" of specialists and flow them in other areas, however, subject to change trends rely on their return, professional development is possible.

Despite the decline, the sugar industry has the appropriate infrastructure to ensure represented warehouse, repair, tool, energy management, mainline facilities, communications networks, transport, communications, specialized business services sectors, etc., allowing it to function smoothly within the existing system, at least we can talk about mutual compliance and substantive servicing subsystems.

For a long time formed the "rules of the game" in the industry and the sugar market, a set of institutions and institutions took shape in certain institutional matrix that regulates relations in the system of production, sale and consumption of sugar and waste sugar production, because existing institutional environment can be considered a prerequisite that provides some possibility of recovery and further development of the industry, because it is through the regulatory framework, quotas, licensing and standardization implemented the vast majority of organizational, technological and administrative measures. On the existing institutional framework could be based on the initial stage and transform it into a process of transformation itself adequately to changes in the sugar industry and the conditions of its environment.

Along with the opportunities and reserves, which the industry has for its development there are a number of limitations that could significantly affect the content or the process of strategy implementation. The most significant constraints for the sugar industry are:

- Technological backwardness and obsolescence of production;

- High specific resource consumption and low efficiency;
- Inefficient production management, poor manufacturing process and ineffective regulation of the sugar market;

- The lack of scientific and technological progress and a low level of innovation;

- A source of social tension;

- Lack of financial resources in the sector and its low investment attractiveness;

- Lack of integration, weak linkages between producers of sugar beet, sugar factories and scientific institutions (Danylyshyn, Strashynska, 2008).

Technological backwardness, outdated equipment is not a major obstacle in the development of the sugar industry in Ukraine. While the majority of the world uses sophisticated equipment, advanced technologies of deep processing of sugar beet, in our country the majority of sugar mills "celebrated" his century, the share of modern equipment is less than $30 \%$, the rest - is extremely outdated. This is why sugar refineries are now three or even two weeks a year, which is extremely unprofitable. Hence the high cost of Ukrainian sugar, its discrepancy with European quality standards, low competitiveness, high loss of electricity, heat, water and, as a consequence - loss of almost all of the industry.

The share of fuel and energy cost of processing 1 ton of sugar beets in the vast majority of Ukrainian plants reaches $35-40 \%$, and its share in the cost of sugar - about 30\%, in some companies, this figure is even higher. The cost of fuel equivalent to the mass of sugar beet in Ukraine in general make 4,5-5\%, while the sugar factories of Europe specific consumption of fuel equivalent to the mass of beets does not exceed 2,5-3,0\% (Lyskov, 2000). Some factories are faced with the problem of reconstruction energy efficiency because of an 80th century. (Increased capacity from 3 thousand tons to 6 thousand/day), which at that time was quite acceptable because of the low cost of energy. Today, businesses operate with the withdrawal of syrup, which accounted re-heated, cleaned, boil - it significantly increases the energy consumption and production costs and reduces efficiency.

Low level of manufacturing process is a result of significant downtime, loss of raw materials and finished products, reduced productivity, inconsistencies in the various stages of production time and more. As external constraints can be considered failure "rules" from the side of the state, creating instability in the industry and reduces the degree of reliability for investors and participants. Ineffective Regulation of destabilizing the manufacturer increases its risks, and reduces the medium- and long-term forecasts and plans, eliminates the motivation to develop.

An important limitation of the industry is insufficient (almost no) introduction of highly efficient equipment and modern advanced technologies, new materials, information technology and so on.

The trend towards the closure of sugar factories, most of which are located in rural areas creates a number of social problems: mass loss of public jobs, reducing its income and 
level of solvency, the destruction of infrastructure created in the zone operation of the factory, including social, etc. Moreover, in addition to usually single employer, sugar factory is a source of heat and electricity for residents of rural areas, stopping one or more factories will cause social strain within certain areas, but the massive closure boom can cause social or even social collapse.

The low level of efficiency associated with a high specific resource consumption and inefficient management and marketing, is a major cause of lack of financial resources needed not only of current activities, but also for development. At the same time, unstable financial state of the industry is causing distrust of the banking system, eliminating its main source of borrowed funds of sugar makes unattractive for investors, thereby closing the "thing devoted circle of poverty". Private investors will provide capital only when they are confident of a competitive return on their investment (Danylyshyn, Strashynska, 2008). This problem has deep roots, for decades lacked financial resources and investment from happening in the required amounts, which gave rise to the problem of technical backwardness, sparing refineries capabilities to implement measures for technical re-equipment and repair.

Insufficient integration of sugar company's sugar beet producers significantly worsens the situation first on a background of continuous decline in economic motivation, for growing sugar beets in the second. The result is an increase in crop beet by sugar plants, and although in the short term it is output and solves the problem of the survival of the sugar industry, but in the future may be destroying factor for agriculture, through modern circumstances forced to violate the rotation, moving on less expensive and more profitable crops. As pointed Valiavska S.M. and Prudka E.A., this approach does not solve the problems of the industry, as in any country except Ukraine, the manufacturer alone does not grow beets for their needs and not deliver them for recycling. This involved farmers and agricultural producers. The state establishes a quota and price of raw materials grown under this quota. Thus, there is no excess production, prices remain stable and balanced.

\section{The system of practical measures}

The set of capabilities and limitations of the sugar industry form a picture of the sector's strategic position at the present stage, we can characterize as extremely weak. Such a situation requires the development and implementation of complex technical and technological, organizational, economic and administrative measures aimed at improving efficiency and resource, industrial, institutional, commercial and social functional subsystems sector.

To achieve the strategic goal in real economic conditions successfully, it is necessary to develop and implement effective integrated and flexible system of practical measures of the sugar industry, which can be divided into three areas:

- Restructuring and technical and technological modernization of the sector;

- Diversification of production;

- Organizational and economic modified sugar production.

The main objectives of these groups of measures is to stabilize production with minimal resources and creating prerequisites for its increase in the future, the financial recovery of the industry, to ensure stable profitability producers to reduce production costs and ensure its competitiveness both in the domestic and foreign markets, achieving full balance production capacity of raw materials, infrastructure and social sphere surrounding areas.

Given the need to implement sub-strategic goal of the sugar industry, providing a gradual transition from the industry crisis economic growth, a set of measures should logically reflect this process, reflecting alternative development opportunities and objective goals. The availability of alternatives makes strategy more flexible and adaptable - to change the value and power of influence of various factors on the availability of alternatives allows the field without much loss to adjust their behaviour or change the path of development.

It should be emphasized that the process of modernization of the sector was obviously the wrong way, all the efforts and resources directed to "intensive care", with often inefficient factories for restoration, repair, partial technical improvements, etc. - thus the industry distanced from the progressive development. Instead the situation that characterizes the state of the industry and market conditions require radical restructuring, both territorial and functional sugar industry in Ukraine, and if we abandon this path, our country will lose one of its traditional industries, hitting a dependence on imports, losing a source of income for workers, employers, and for the budget against the backdrop of the general economic crisis will cause a negative multiplier effect, causing a reduction in the chain of production and consumption in the macroeconomic scale. No alternative restructuring of sugar in modern conditions and international experience proves, Western European countries put out of operation thin, unprofitable and unpromising businesses, reconstructed, promising increased capacity and received efficient sugar industry. And the experience of these countries shows the same gradual technical adjustment as rapid changes in the structure of the sugar industry in Ukraine is not only impossible financially and technically, but also threaten social explosion. That is why our country needs its own unique program of transformation of the sugar industry, which consists of successive stages and should be implemented gradually in view of the difficult economic situation and industry, and agriculture, and the country as a whole.

Thus, in the first block, in accordance with the principle of consistency, should take measures: 
- Gradual decommissioning wasted low sugar factories; - Technical reconstruction and modernization of the industry by raising technical, technological and organizational level of production. It must be emphasized that the initial focus should be on those parts of the process where it is possible to obtain the greatest effect as in saving resources, including energy, and to obtain additional revenue through, for example, deep and complex processing of raw materials, improve the quality of the final and intermediates etc.

- Restructuring the industry through consolidation and concentration of production capacity increase for companies that provide effective production of products, raw balancing zones and production capacity. Since the process of closure of inefficient enterprises already happening naturally (in 1990 employed 192 factories, in $2014-46$ and in 2015 - 35) under the influence of market, political and economic changes in the country and on the world sugar market, should focus on promising businesses to bring their capacity to economically optimal to ensure the minimum average costs. There are two possible alternatives: reconstruction and modernization and new construction, with both advantages and disadvantages and effectively elected or combined depending on the conditions, the feasibility of production at a particular plant, development prospects, the state of the respective raw zones etc.

- The introduction of new innovative waste or lowwaste and clean technologies using modern highly efficient equipment and equipment, alternative energy, new materials, etc., which allow to increase volumes of extraction of sugar, receive high-quality co-products, including energy;

- Technical and technological support intensification of production;

- The creation of an efficient infrastructure through reorganization of transportation, storage, handling both raw materials and finished product in order to reduce their costs and improve the efficiency of primary production and modernization of the energy, repair, tool households to reduce the value of the corresponding components in cost of production;

- Production ecologization (reduction of emissions, introduction of energy saving technologies, etc.).

The core strategy of the sugar industry has become a major diversification that due to production in the sugar factories of other products and expanding the production program will, as the Lyskovo V.V., increase trade turnover, expand the financial base, dynamic and efficient use of production reserves, increase efficiency and profitability of companies (Lyskov, 2000). The trajectory of development should provide the ultimate movement of sugar factory (single product) to the sugar mill (poly product) since diversified companies are more sustainable and competitive compared to highly specialized and have not only the possibility of redistribution of capital in favor of more profitable types of production and support thus less profitable but also to minimize the possibility of industrial and commercial risks. Given the seasonality of the sugar production diversification will align its load, eliminating downtime, increase efficiency of fixed assets and work, for what periods of maximum load capacity of sugar and other industries do not have to be the same, but the core production program thus has to be sugar production. In terms of diversification is expected to take a number of measures:

- Expand and improve the range of products of sugar production through the development and expansion of different types of sugars ("Coca-cola's", candy, mint, adding cinnamon and ginger, etc.), gelling products based on sugar, sugar lipstick and depth recycling and obtaining by-products - molasses (followed by the production of dry molasses concentrate, including the transfer of sucrose in its calcium salt, not counting the fact that molasses is a traditional material for the production of alcohol and yeast, glycerine, lactic and citric acids, a component of animal feed, etc.), pulp (production of dry feed, pectin glue for the textile industry and so on.), food pectin, sugar factory lime (production on its base fertilizer-melioration mixtures and cement) after alcohol bards, molasses (which today is scarce resource for the production of alcohol and high-oxygen additive to gasoline) and others Experts of sugar industry counted that existing demand in Ukraine for described products and substances, can't be satisfied by operating factories, indicating that the market has a large capacity and opens up attractive prospects and potential for growth and development of the sector;

- Development and expansion of biofuel production through a combination of technological and organizational processes of production of sugar, bioethanol, biogas and solid fuels, which will solve the problem of energy supply and energy independence sugar industry, keep the area existing, workplaces, reduce production costs, improve product competitiveness. The first phase is possible by mounting the sugar factories settings (Danylyshyn, Strashynska, 2008), in the long term requires deep technical modernization and reconstruction of refineries on the basis of directions of diversification. Studies show that sugar beets aren't the best $\mathrm{n}$ the raw material for fuel, but one of the most effective in Ukraine in connection with high performance and significant output of bioethanol from 1 ha of crops - about 4,62 tons. According to experts, domestic bioenergy could absorb and sugar factories adapt, sugar beets grown on an area of even 1 million and the forecast calculations Doronin A.V. in 2020, for the production of biofuels for domestic and foreign markets, with full self-supporting sugar to be involved 87 sugar plants (Danylyshyn, Strashynska, 2008);

- Introduction of flexible manufacturing technologies that allow the transition to another type of product (eg sugar for biofuels and vice versa) depending on market conditions and trends emerging in the domestic and foreign markets;

- Development of international scientific and technical cooperation in the field of technology. 
Block of organizational and economic modifications of sugar production includes:

- The introduction of advanced forms of production and work to streamline processes and reduce the loss of all kinds of resources;

- The integration of sugar beet producers and sugar companies, the introduction of the contract system of relations, the formation of agricultural clusters and more. Specifically, L.V. Strashynska considers that the system of integration interaction of participants on a contract basis is the most convenient and easy because within this integration is quite easy to change the scope of cooperation - the related adjustment as the number of participants and volume of their mutual obligations, which is especially important during volatile market conditions . Contracting requires much less time compared to the other options of vertical integration of production (Danylyshyn, Strashynska, 2008). Today, as already noted, is dominated by a tendency to self-Sugar cultivation of raw materials for their own needs. Most manufacturers support this trend, seeking to reduce their own risks associated with the provision of raw materials, and the future is seen by them for this approach. However, it should be noted that a similar scheme in the first place, contrary to the logic of the social division of labour and is not used in any country in the world, and secondly, reduces the effectiveness of both beet and sugar production, depriving agriculture traditional activities, and Sugar - burdened with additional features and risks, although initially this situation is quite acceptable because of the difficult situation in the sector. Ultimately, a mature market system will create conditions for mutually beneficial interaction between sugar mills and sowing beets enterprises based on economic motivation profit, while support and motivation for cultivation sugar beet $\mathrm{s}$ by farms must take the state as culture quite demanding and less profitable than others;

- Reorganization management industry as a whole and now including the introduction of modern management concepts, marketing strategies, information technology decision support;

- Creating an effective and flexible information technology planning production of sugar, ongoing monitoring of the state of internal and external environment and its changes carried out as a direct and indirect impact on production;

- Restoration quality scientific, technical and staffing industry development mechanism implementation of scientific achievements in sugar production;

- Restoration and improvement of the system of continuous training and skills development for the sugar industry;

- Providing technical, sanitary and phytosanitary rules greener production processes and products according to international standards, improving product quality;

- Organization process of passing international certification in order to increase export potential and expand into new markets;
- Development and introduction of branch system of monitoring and forecasting of domestic and foreign markets;

- The creation of specialized technology parks.

\section{The mechanism of implementing the strategy}

The condition for the effective implementation of the development strategy of the sugar industry has become an effective mechanism in the classical sense is a "converter" technical, technological, economic and organizational efforts and investments of Sugar on a pre-planned results, revenues, profits, production, competitive position in domestic and foreign markets and more. It includes a set of tools, a set of methods and means of influence on economic processes that ensure implementation of measures and achievement of strategic objectives, and consists of two subsystems - providing and functional. The first subsystem includes planning tools, encouragement, motivation, control, and the second - the tools of financial, material and staffing process development strategy.

Functional subsystem includes:

- Continuous monitoring of the situation and the impact on decision-making in the implementation of the strategy; - Organization of communications staff in the implementation of the strategy, a joint adjustment of their actions;

- Motivation of staff;

- Risk management.

Providing subsystem includes:

- Available financial potential of the sector;

- A mechanism to attract investment. Total investment required for a deep restructuring and modernization of the industry exceeds the capacity of the state and the possibility of sugar factories, as the mechanism provides flexible combination of public and private investment;

- Technical support of implementation of the strategy.

In the process of implementing the strategy, any system is experiencing ongoing impact of the external environment, and therefore reacts to these influences, changing the trajectory of development, is trying to adjust to minimize loss or maximize your win. The mechanism of implementing the strategy should take account of these changes, an appropriate adjustment strategy, increasing its flexibility and adaptability. The sooner adjustments are made to the forecasts, strategic, tactical and operational plans, the more effective mechanism.

The mechanism of implementation of the strategy involves selection of the optimum combination of actions (options) for each stage of development that most adequately correspond to the trajectory of the realization of strategic objectives and conditions of the external and internal environment of the industry.

The criterion of effectiveness of the mechanism development strategy is the simultaneous fulfilment of the following conditions: 
- The efficient use of capacities;

- Meet the demand for the products of the industry;

- The availability of sufficient financial resources at every stage;

- Logical sequence of implementing measures.

No matter how effective was not a mechanism for implementing the development strategy of the sugar industry, it can not independently provide one hundred percent the strategic goal, as the industry is working in a particular institutional environment, which, as noted earlier, includes formal and informal institutions that create conditions and "rules" in. In particular, at the state level is provided:

- Regulatory and legislative functioning and development of the sector;

- Regulatory policies;

- The creation of investment climate;

- Development of mechanisms of subsidies and preferential loans Sugar, credit incentives and state guarantees for loans;

- Legislative restriction of the use of sugar substitutes;

- Formation of the system of international relations that affect the export-import operations, creating conditions for interstate industrial cooperation, implementation of state policy to stimulate exports of sugar;
- The implementation of economic policies: fiscal, monetary, investment, innovation, structural, social;

- Implementation of foreign policy: protectionism or free trade.

Some impact on the field of exercise and informal institutes and institutions, so the best scenario development strategy Ukraine's sugar industry can only be a harmonious combination of intra mechanism for implementing existing instruments with institutional environment.

\section{Conclusions}

The implementation of the proposed measures will overcome the crisis on the first phase, on the second - stabilize production and create conditions for increasing it in the future and, finally, ensure economic growth in the long term.

With the successful implementation of the development strategy of the sugar industry, the efficiency and effectiveness of the proposed technical and technological, economic and organizational measures can be expected positive changes in the socio-economic field, the reconstruction and stabilization of Sugar in the domestic sugar market, economic growth in the future, new jobs, improve social conditions of workers in the industry, winning stable positions on foreign markets.

\section{References}

Agricultural development strategy until 2020. (2012). - [Electronic resources]. - Retrieved January 17, 2016 from http://www.auu.org.ua/rynky-ta-ciny/novini-rinkiv

Danylyshyn, B.M. (Ed.), Strashynska L.V. (2008). Strategy of development of food market in Ukraine: monograph Kiev, Profi, 627 p.

Lyskov, V.V. (2000). The formation of an efficient structure of the sugar industry of Ukraine - Kiev, Institute of Economics national Academy of Sciences of Ukraine, $210 \mathrm{p}$.

\section{Юлия ОНИЩУК}

\section{СТРАТЕГИЯ РАЗВИТИЯ САХАРНОЙ ПРОМЫШЛЕННОСТИ В КОНТЕКСТЕ ЕВРОПЕЙСКОЙ ИНТЕГРАЦИИ УКРАИНЫ}

Аннотация. Основной проблемой украинской экономики сегодня является тотальная потеря производственного потенциала. Теряя производство, страна превращается в аутсайдера мировой экономики, "выпадает" из системы международного разделения труда, отдавая лидерство в производстве традиционных для нее товаров странам, имеющим меньшие преимущества, но более цивилизованный подход к производству. Одним из таких традиционных товаров, который всегда был “визитной карточкой” Украины, является сахар. Методология. Основой методологии для проведения исследований развития сахарной промышленности нами был выбран системный подход, в рамках которого отрасль рассматривается как сложная, структурно завершенная система элементов объединенных общей целью. В то же время сахарная промышленность является подсистемой пищевой промышленности, входит в состав перерабатывающей и выступает элементом агропромышленного комплекса. Исследование отрасли как системы и составляющей системы более высокого порядка обусловлено необходимостью обеспечения максимального уровня эффективности ее развития. Развитие сахарной отрасли Украины должно быть не простым переходом от одного качества системы к другой, а сложным многофакторным процессом, отражает действие закона перехода количественных изменений в качественные. Реализация же основной цели развития сахарной отрасли в условиях динамичной внешней среды возможна только при условии выбора и реализации эффективной стратегии, которая должна быть встроенной в стратегию развития АПК и общегосударственную экономическую стратегию. Поэтому предметом нашего исследования являются теоретические 
Vol. 2, No. 1, 2016

и прикладные аспекты эффективного развития сахарной промышленности Украины, а целью исследования - разработка стратегии развития отрасли в условиях евроинтеграции. Результаты. Под стратегией развития сахарной отрасли мы понимаем уникальный набор действий и решений относительно способов достижения целей развития с минимальными затратами энергии системы. Считаем, что стратегической целью должно стать создание современной, технологически совершенной, экономически эффективной и социально значимой сахарной отрасли, способной производить конкурентоспособную продукцию, удовлетворять в полной мере внутренний спрос на сахар, обеспечивать формирование государственного резерва и расширять экспортную базу. Для достижения этой цели отрасль имеет ряд предпосылок, которые рассматриваются как ее возможности, а также ряд ограничений, тормозящих процесс развития, могут существенно повлиять на содержание стратегии или на процесс ее реализации и требуют устранения. Вместе они формируют стратегическую позицию сахарной отрасли, которую сегодня мы можем характеризовать как очень слабую. Достижение стратегической цели предполагает разработку и реализацию целого комплекса мероприятий, которые мы разделили на три направления: мероприятия по реструктуризации и технико-технологической модернизации отрасли, меры по диверсификации производства и меры по организационно-экономической модификации сахарного производства. Значение/оригинальность. Реализация предложенных мероприятий позволит на первом этапе преодолеть кризисные явления в отрасли, на втором - стабилизировать производство и создать предпосылки для его наращивания в будущем и, наконец, обеспечит экономический рост в долгосрочной перспективе. 